\title{
The benefits of geospatial planning in energy access- A case study on Ethiopia
}

\begin{abstract}
Access to clean and affordable modern energy is crucial to fostering social and economic development and to achieving the Sustainable Development Goals. Efficient policy frameworks and effective electrification programs are required in order to ensure that people are electrified in a sustainable manner. These programs differ from country to country depending on geographic and socioeconomic conditions. Electrification planning process must consider the geographical characteristics of the resources as well as the spatial dimension of social and economic drivers of energy demand in order to find the most optimal energy access solution. Geographical theory and Geographic Information Systems (GIS) in particular can play a significant role in electrification planning, since they are capable of managing the data needed in the decision making process and may integrate and assess all possible options. This paper focuses on considering these characteristics by applying a recently developed GIS based methodology to inform electrification planning and strategies in Ethiopia. The paper illustrates two major aspects of energy planning; 1.) how the optimal electrification mix is influenced by a range of parameters - including population density, existing and planned transmission networks and power plants, economic activities, tariffs for grid-based electricity, technology costs for mini-grid and off-grid systems, and fuel costs for consumers and 2.) how the electrification mix differs from location to location. For a certain level of energy access, ongrid connections would be optimal for the majority of the new connections in Ethiopia; grid extension constitutes the lowest cost option for approximately $93 \%$ of the newly electrified population in this modelling effort with 2030 as time horizon. However, there are some remote areas with low population density where a mini-grid (ca. 6\%) or a stand-alone solution (ca. 1\%) are the most economic options. Depending on local resource availability, these systems deploy varied combinations of solar, wind, hydro and diesel technologies.
\end{abstract}

Keywords: GIS; Energy planning; Energy access; 


\section{Introduction}

Around $18 \%$ of the world's population lack access to electricity, the large majority of whom reside in rural regions of developing countries. Providing universal energy access has become a fundamental humanitarian goal, which is vital to ensure economic and social development (IEA, 2014a). Universal access to electricity by 2030 is one of the key goals of the UN Sustainable Energy for All (SE4All) initiative (SE4ALL, 2015). Universal access to sustainable, affordable and reliable energy is highlighted in the $7^{\text {th }}$ Sustainable Development Goal (SDG). Special importance in given to expansion and upgrading of technology to supply energy services to developing countries (UNDESA, 2015a). While the need for increased electrification rates in developing countries is widely recognised in national policies (WHO, 2009), (IEA, 2011), there are diverging views on how to achieve those. Development of effective electricity distribution has several geographical dimensions thus giving different outcomes in terms of spatial distribution of development. Energy system evolution is inherently linked to geographical characteristics of an area, such as local resources availability, distance from roads and power infrastructure, economic activities and settlement structures. Commonly, one electrification option, such as grid extension, mini-grid or stand-alone connection, is preferred over another for various reasons depending on perspective, background, financial capacity and competence of the implementing body. The spatial organisation of the different options at hand result in different degrees of spatial differentiation thus influencing inequality within and among countries (Balta-Ozkan et al., 2015; Nijkamp, 1980). Therefore, energy planning needs to relate not only to the thematic energy related SDG but also consider how energy systems influence inequality within and among countries as outlined in the $10^{\text {th }}$ SDG (UNDESA, 2015a).

Electrification planning and thus the resulting technology choices often depart from an understanding of the spatial structure and distribution of the population and economic activities. These choices are based on as accurate as possible estimation of the societal needs and economic demands versus the costs of electric infrastructure investments. However, existing proxies such as population density prove inadequate to estimate costs at a national level since the latter are motivated by additional geospatial attributes, which are mentioned throughout this study.

The general paucity of reliable energy-related information, socio-economic and geo-referenced data in Africa hampers analysis and planning (Pollet et al., 2016). Access to such information and data is however crucial for assessing, planning, implementing and monitoring basic energy services delivery. The use of ground level geospatial data is quintessential to identify the most effective electrification strategy for universal energy access. However, such geospatial data are often non-inexistent, fragmented, or inconsistent and their use for strategic planning at national levels remains in an early stage.

The integration of energy system models and Geographic Information Systems (GIS) and the development of combined tools is essential to better understand the spatio-temporal dynamics of energy planning. This paper applies such a methodology drawing on GIS tools and remote sensing data to fill data gaps in national databases, such as renewable energy resources, actual costs of diesel at the point of consumption, population density linked to energy demand and transmission infrastructure (Mentis et al., 2015). 
Ethiopia is chosen as a case study for spatial electrification planning as the country's per capita electricity consumption is among the lowest globally. Ethiopia's current per capita use amounts to $52 \mathrm{kWh}$ - dismal compared to neighbouring Egypt (1743 $\mathrm{kWh} / \mathrm{cap})$ or the USA $(13,246 \mathrm{kWh} / \mathrm{cap})$ (SE4ALL, 2015). Increasing cost effective and affordable access to electricity and the services it provides is paramount for meeting SDG 7. Also, the local renewable energy potential is significant in size. The wind and solar power potential in the country are noteworthy (IRENA, 2014; Mentis et al., 2015). However, the country is struggling to provide its citizens with access to electricity as it has one of the lowest rates of electricity generation per capita in the world and supply falls short of demand resulting in load shedding, black outs and a reliance on private generators. To illustrate, just over $26 \%$ of the country's population has access to electricity (24 million out of 92 million in 2012). In rural areas this figure drops to $10 \%$ (IEA, 2014b).

The structure of the paper is as follows: This introduction is followed by a description of the existing applications of GIS tools in energy and electricity planning and renewable energy assessments. The literature review serves to underline the need for a comprehensive geospatial electrification planning approach, which is described in detail in Section 2. That section first lists and describes the datasets needed for such a GIS based electrification assessment. Thereafter, an electrification analysis is carried out using urban and rural energy access targets ${ }^{1}$. Section 3 presents the results of this work. Section 4 discusses the findings of this study and Section 5 wraps up the paper with conclusions regarding next steps and possible enhancements.

\subsection{GIS for energy systems and energy planning}

Energy system planning is essential in order to match demand and supply, where cost minimization is a primary objective. Moving from centralized electricity generation and costly transmission and distribution, hence expensive to connect the currently unconnected, towards fluctuating, decentralized and cost effective renewable energy production necessitates considerable modifications of energy infrastructure (Resch et al., 2014). Even though local approaches to electrification are inherently motivated by geospatial questions and challenges, the integration of GIS and energy system analysis and planning tools is still in its infancy.

The availability of tools such as GIS and enhanced computing power has facilitated multivariable and multiscale analyses and integration of spatial data to study the impact of geographical issues such as neighborhood effects, clustering and increased and or decreased spatial inequality. Studies of spatial variability in disciplines such as remote sensing (Quattrochi and Goodchild, 1997), landscape ecology (Turner, 1989), geomorphology (Phillips, 1988), hydrology (Blöschl and Sivapalan, 1995), population and economic geography (Archila Bustos et al., 2015) have used GIS as a tool for analysis since the 1980s.

In the context of our study there are several recent studies on energy planning and renewable resource assessment, spanning from local (Palaiologou et al., 2011), (Quinonez-Varela et al., 2007), (Gormally et al., 2012),(Miller and Li, 2014), (Calvert and Mabee, 2015) national studies (Siyal et al., 2015), (Sahai, 2013), (Bekele and Tadesse, 2012),(Aydin et al., 2013) to regional

\footnotetext{
${ }^{1}$ KTH Division of Energy Systems Analysis collaborated with the International Energy Agency in order to contribute to the Africa Energy Outlook, 2014. Current electrification rates and electrification access targets were provided by IEA.
} 
studies (Sørensen and Meibom, 1999), (ESMAP, 2015),(Mentis et al., 2015), (IRENA, 2014), (Archer and Jacobson, 2013) taking the spatial dimension into account. However, these studies do not consider explicitly the spatial effects. Several concepts from geography can be applied within the context of energy planning. Distribution systems for energy have a clearly spatial dimension and can influence regional inequality (Ye and Wei, 2005). The level of regional inequality differ across the spatial scale as discussed by (Turner, 1989). (Wei, 2015) conclude that most studies are conducted on subnational level across administrative units but to a less degree between nations.

In most cases, planning energy distribution systems is essentially reduced to the choice between centralized or de-centralized systems. Centralized distribution systems focus on a structure exploiting economies of scale at large generation and transmission and distribution infrastructure (Künneke, 2008). However, the growing sensitivity to environmental issues, the development of information and communication technologies, as well as the fall in the minimum efficient scale following the introduction of new distributed solutions have been powerful drivers in the transition to decentralized and deregulated systems with a modal split consisting of different solutions (Pollitt, 2008).

According to the literature review, the usage of GIS is mainly focusing on generation of spatial data used as input in scenario development for energy systems. The outcome is helping us to understand how spatial data such as population density, solar reflection, the division between rural and urban settlements influence the optimal solutions to energy access. Our study provides, not only the development of aspects using spatial data to generate different scenarios, but also an evaluation of the different scenarios outcome in terms of spatial inequality.

\section{Methodology}

Due to a plethora of parameters, supply systems providing cost effective electricity to households are diverse and site specific. The cost-optimal technology choice thus depends on several parameters - geophysical, technical, economic or social - ranging from population density, distance from the nearest grid, fuel and technology costs, electricity demand, finance and energy resource endowment, all of which are strongly spatial in nature. Wind regimes, potential mini-hydro sites, settlement locations, grid expansion are examples. The challenge for modelling access goals with results suitable for effective policy formulation is then to account for these parameters geographically and quantitatively, to translate and integrate them into a suite of technology options and to carry out analyses in a transparent manner. Until recently the spatial dimension used to be the Achilles heel of such analyses.

Geographical Information Systems based modelling now offers a remedy by enabling the analyst to assess the cost of electricity provision for any specific location in a given area. By combining detailed geospatially referenced layers of data for each of the relevant parameters, 
site specific investment needs and energy cost implications of different technological configurations can be compared in space and time ${ }^{2}$.

GIS tools serve numerous purposes. The following three examples highlight the strength of using spatial data and methods in energy planning:

- Filling data gaps - Remote sensing techniques allow the data collection (generation) of otherwise unavailable location specific data. In this paper, the results from a detailed renewable energy mapping exercise performed by the Royal Institute of Technology (KTH) for the International Renewable Energy Agency (IRENA) were integrated in the analysis, considering a set of socioeconomic and geographic restrictions and technical performance of the chosen technologies (IRENA, 2014).

- Assessments of energy related geospatial information - Traditional energy supply models usually cannot differentiate location specificity (Loulou et al., 2005, IIASA, 1981, Howells et al., 2011)). In this paper, GIS is used to derive location based population and electricity demand projections for urban vs. rural areas using a $2.5 \times 2.5$ sq.km grid cell size.

- Visualization and communications of the results - GIS can be conveniently used to display results in an easy to grasp manner via interactive maps. For example, maps can be generated to show the modal split of electrification at provincial or community levels. Such maps provide an effective science-policy interface. Key indicators for electrification planning are communicated "at-a-glance" to the usually time-poor policy makers.

A flow chart of the methodology and the main steps undertaken in this study are illustrated in Figure 1. Based on this flowchart, the GIS electrification expansion tool is programmed to derive the optimal split in a country in terms of on grid, mini grid and stand-alone solutions. The tool is applied to Ethiopia, which has an area of 1.127 million $\mathrm{km}^{2}$ and is located between latitude $3.5^{\circ}$ and $14.9^{\circ}$ North and longitude $33^{\circ}$ and $48^{\circ}$ East.

The initial step of the analysis is the capture of the current status of the country by utilizing basic GIS data. These data serve as an input to an electrification model created in Visual Basic. The model calculates the least cost split between on grid and off grid electrification based on a set of assumptions on energy resource availabilities, infrastructure, technology and fuel costs, which are described in the following section and in more detail by (Fuso Nerini et al., 2015). The model also details the types of off grid solutions, i.e. the optimal split between mini grid and stand-alone systems. Further, the corresponding LCOE is calculated. Results are graphically represented on maps as well as in tabular format.

\footnotetext{
${ }^{2}$ In this context, the IEA World Energy Outlook included results from the spatial electrification tool applied to the cases of Nigeria, Ethiopia (IEA, 2014c) and India (IEA, 2015).
} 


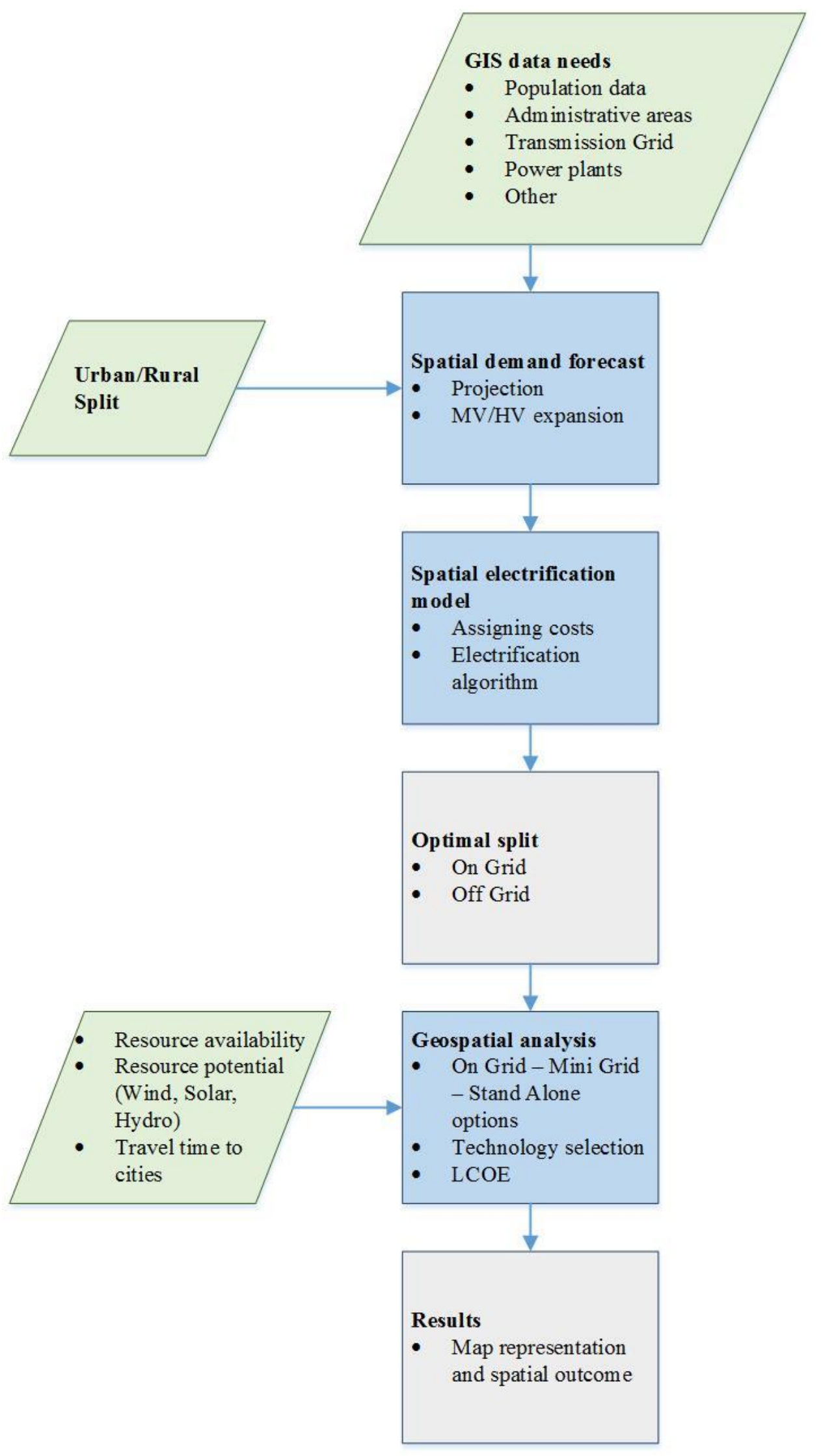

Figure 1: Logical Methodological: Flow chart applied to perform electrification planning ${ }^{3}$

${ }^{3}$ Colour convention: Light green shows "data", blue shows "process/analysis" and light gray "results/products of the assessment" 


\section{$2.1 \quad$ GIS data needs}

The current electrification status of the country was captured by extracting basic open source GIS data, such as population density, administrative areas, transmission network and power plants from existing geospatial datasets. The data used for the analysis and the corresponding sources are listed in Table 1

Table 1: GIS datasets used in the electrification planning analysis

Dataset

(GADM, 2012).

$\operatorname{AfDB}(2011)$.

AfDB (2011).

JRC (2008)

USGS (2014)

Linard et al. (2012)

IRENA (2014)

Authors calculations

\section{Thematic Theme}

Administrative Areas

Energy Transmission

Power plant location

Travel time to big cities

Mining reserves

Population

Solar and wind potential

Mini hydropower potential
Type of data

Vector

Network

Vector

Network

Vector

Grid

Raster

Vector
Point location

Spatial Scope and Proxy

Administrative levels 1 to 3

Distance to grid

Point location

Transport cost

Economic activities

Demand projection (Cell size 2.5

$\mathrm{km})$

Renewable Energy resources

(Solar: $0.25 \%$ Wind: $0.1^{\circ}$ )

\subsection{Spatial electricity demand forecast and planned grid expansion}

Building on these datasets, projections to 2030 were made regarding population density and electricity demand. These projections are based on the current population, population growth and on whether settlements are considered urban or rural. Population growth rates were applied to the population map in order to obtain the expected population in the time frame of the analysis $(2015-2030)^{4}$.

\footnotetext{
${ }^{4}$ Population growth rates were provided by the International Energy Agency
} 
Regarding the definitions of urban and rural areas, these differ from country to country. Hence, countries must establish their own definitions in accordance with their own needs (UNDESA, 2013). The traditional distinction between urban and rural areas within a country is based on the assumption that urban areas provide a different way of life and usually a higher standard of living than what is found in rural areas.

Energy access targets were agreed with the International Energy Agency to be 150 $\mathrm{kWh} / \mathrm{capita} /$ year for rural and $300 \mathrm{kWh} / \mathrm{capita} /$ year for urban areas. Urban areas in Ethiopia have a population density of greater than 150 people per $\mathrm{km}^{2}$ and are located within 1 hour travel time from a city of at least 50,000 people (IFPRI, 2009).

Future HV transmission lines expansions are assumed to occur based on three criterias:

- compliance with the African Development Bank's transmission expansion plan (AfDB, 2011)

- connection of power plants and those under construction and in a planning stage (AfDB, 2011)

- connection of unconnected mines via MV connectors grid (USGS, 2014)

For mines located close enough to the existing grid, MV connections to the main grid are preferable over HV lines in terms of investment costs and electricity losses. Thus, MV lines are assumed to be used in these cases (refer to MV line length limit described in Section 2.3.2.).

Further, if cost-efficient compared to mini- and stand-alone solutions, MV and LV lines are considered for connecting settlements based on factors such as distance to the grid, population data, the urban/rural split and associated cost assumptions, as further outlined in the following sections. The transmission expansion steps are presented in the following maps.

First, the administrative area of Ethiopia and high resolution population density map are shown in Figure 2. On top of the latter map, the existing transmission HV lines and power plants are overlaid (Figure 3).

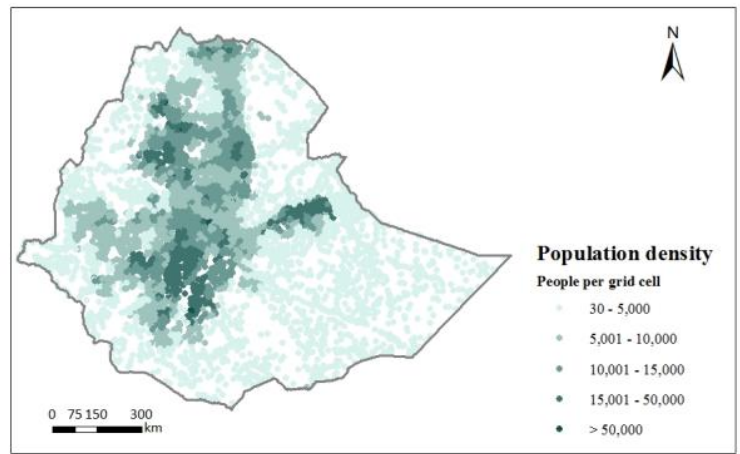

Figure 2: Population density in Ethiopia given in people per grid cell (approximately $2.5 \mathrm{~km} \times 2.5 \mathrm{~km}$ size) 


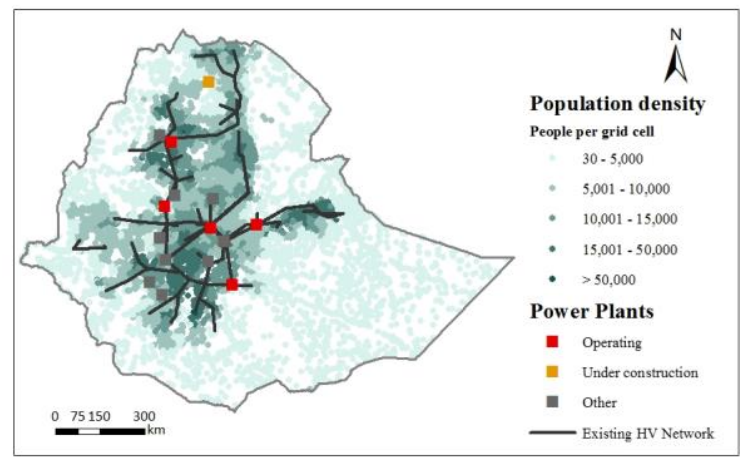

Figure 3: Population density, existing transmission HV transmission network and power plants (right) ${ }^{5}$.

The following map shows the projected population density (based on the current GIS dataset of population density and projections for 2030 (UNDESA, 2015b), the existing and planned transmission HV lines as described above (Figure 4).

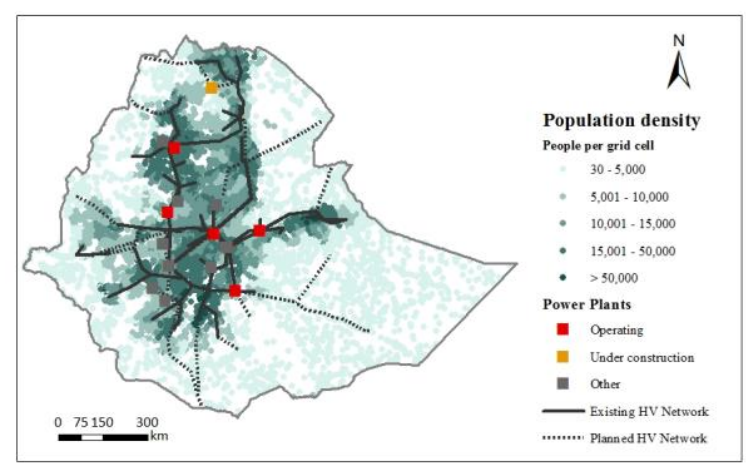

Figure 4: Existing and planned transmission HV lines and power plants and mines

\subsection{Electrification model}

\subsubsection{Assigning costs}

The electrification options analyzed in the study included three categories: grid connections, mini-grid systems and stand-alone systems (see Table 2). The considered supply technologies were chosen as a matrix mature technologies for electrification and depending on GIS data availability. For every GIS cell, the LCOE of these options are evaluated by a simple cost model. The resulting LCOE information is fed into the GIS model to determine the most economical option for each grid cell given its geospatial characteristics.

Table 2: Technologies compared for energy access

\begin{tabular}{|l|l|}
\hline Category & Supply technology \\
\hline Grid connection (Grid) & National grid \\
\hline Mini grid systems (MG) & $\begin{array}{l}\text { Solar PV } \\
\text { Wind turbines }\end{array}$ \\
\hline
\end{tabular}

\footnotetext{
${ }^{5}$ Other power plants are referred to planned power plants and mines that are not connected to the main grid yet.
} 


\begin{tabular}{|l|l|}
\hline & $\begin{array}{l}\text { Diesel generators } \\
\text { Mini-Hydro }\end{array}$ \\
\hline Stand-alone systems (SA) & Solar PV \\
& Diesel generators \\
\hline
\end{tabular}

For the LCOE calculations, four parameters are considered and connected to costs:

a. Target level and quality of energy access, i.e., the amount of electricity that the electrified households are or will be (in case they are not electrified) provided with, measured in $\mathrm{kWh} / \mathrm{household} /$ year.

b. Population density, measured in Households $/ \mathrm{km}^{2}$.

c. Local grid connection characteristics including the distance from the nearest grid $(\mathrm{km})$, and the average national cost of grid electricity $(\$ / \mathrm{kWh})$.

d. Local renewable energy resources availability and diesel costs to evaluate the costs of the different electrification alternatives.

The LCOE of a specific technology option represents the final cost of electricity required for the overall system to breakeven over the project lifetime. It is obtained with the following equation (Fuso Nerini et al., 2015)

(1)

$$
L C O E=\frac{\sum_{t=1}^{n} \frac{I_{t}+O \& M_{t}+F_{t}}{(1+r)^{t}}}{\sum_{t=1}^{n} \frac{E_{t}}{(1+r)^{t}}}
$$

$I_{t}$ is the investment expenditure for a specific system in year $t, O \& M_{t}$ are the operation and maintenance and $F_{t}$ the fuel expenditures, $E_{t}$ is the generated electricity, $r$ the discount rate and $n$ the lifetime of the system. Thereafter, the power generation capacity for mini-grid and standalone solutions is calculated based on the electricity access rates.

Note: The LCOE calculations for the mini grid and stand-alone electrification options reflect the total system costs while the LCOE for the grid option is the sum of the average LCOE of the national grid plus the marginal LCOE of transmitting and distributing electricity from the national grid to the demand location. A detailed description of the model can be found in (Fuso Nerini et al., 2015).

\subsubsection{Electrification algorithm}

The GIS analysis of a settlement's suitability for grid connection uses two separate, yet complementary inputs ${ }^{6}$. First a settlement table referencing each settlement's position, i.e., its $\mathrm{x}$ and y coordinates on the GIS map, and its initial status in terms of electrification listed as either 1 (electrified) or 0 (non-electrified). To obtain the initial status, it is assumed that the population within a certain distance from the HV grid and a certain population density is equal to the electrified population of the country, i.e. $85.2 \%$ of urban and $10.4 \%$ of rural population have access to electricity (26\% national rate) (IEA, 2014b).

\footnotetext{
${ }^{6}$ The algorithm used is written in Excel VBA (2013).
} 
Second, the procedure uses a reference matrix of standard distances to the grid and the minimum population requirements for grid connection to be competitive. The standard distances are multiples of the $2.5 \mathrm{~km}$ grid cell (or settlement) width. This matrix depends on the targeted level of electrification and the relative LCOEs (see section 2.3.1).

Based on the settlements table and the reference matrix, the algorithm evaluates if the minimum population requirement is fulfilled to justify an extension of the main grid to the settlement. For each grid connected cell, all non-electrified cells are iteratively checked to test whether or not conditions for their connection to the electrified cell are fulfilled. These conditions include (a) a higher number of people (and thus a higher demand) than the minimum demand required to justify a connection (depending on the distance to the grid electrified cell, and (b) a connection must not exceed the additional MV grid length by more than $50 \mathrm{~km}^{7}$. If these conditions are met, the settlement status is switched to grid electrified (or 1).

The algorithm stores the length of any additionally built MV grid length - a requirement to ensure all newly electrified cells comply with the $50 \mathrm{~km}$ limit for MV line extensions. Further, this is also used to consider cost increases for each additional MV extension, due to the requirement to strengthen the previously built grid connections. This is achieved by linearly increasing the minimum demand (i.e., minimum population per grid cell) required to justify an MV extension with each additional electrification step.

This process is repeated with the newly electrified cells until no additional cells are being electrified, and thus until all settlements to which the grid can be economically extended are reached.

\subsection{Geospatial resource availability}

To calculate the LCOE of diesel generators, the national diesel price (average prevailing in major cities) and the distance from each grid point to cities are considered. The calculation of the diesel-based generating costs is done in three steps ${ }^{8}$. First, the transport cost is enumerated taking into account the national diesel price, the diesel consumption of a truck, the volume of the truck and the transportation time. Then, the electricity generation cost is calculated considering the conversion efficiency of a diesel generator. Finally, the LCOE is derived by adding labour, maintenance and amortization costs to the fuel costs as shown in the computations below.

Transport cost $\left(\$ / k W h_{t h}\right)$

(1)

$$
P_{t}=2 * \frac{P_{d} * c * t}{V} * \frac{1}{L H V}
$$

Where $P_{d}$ is the national market price of diesel $(\$ / 1), c$ the diesel consumption $(1 / \mathrm{h})$ of trucks, $\mathrm{t}$ is the transport time (h) and $\mathrm{V}$ the volume of diesel transported (l) and $L H V_{d}$ is the lower heating value of diesel $(\mathrm{kWh} / \mathrm{l})$.

\section{Electricity generating cost $\left(\$ / k W h_{e l}\right)$}

\footnotetext{
${ }^{7}$ The $50 \mathrm{~km}$ limit is a techno economic limit set for MV lines expansion (Szabó et al., 2011).

${ }^{8}$ These steps are described in detail by Szabó et al. (2013)
} 
(2)

$$
P_{p}=\left(\frac{P_{d}}{L H V_{d}}+P_{t}\right) / \eta+P_{O \& M}
$$

Where $\eta$ is the electrical conversion efficiency of the diesel generator $\left(\mathrm{kWh}_{\mathrm{e}} / \mathrm{kWh}_{\mathrm{th}}\right)$ and $P_{O \& M}$ the labour, maintenance and amortization costs.

The total LCOE of diesel generated electricity is given by the following formula:

(3)

$$
P_{p}=\left(P_{d}+2 * \frac{P_{d} * c * t}{V}\right) * \frac{1}{\eta * L H V_{d}}+P_{O \& M}
$$

The following map shows the spatial variance of the electricity costs per $\mathrm{kWh}$ delivered by diesel generators (Figure 5).

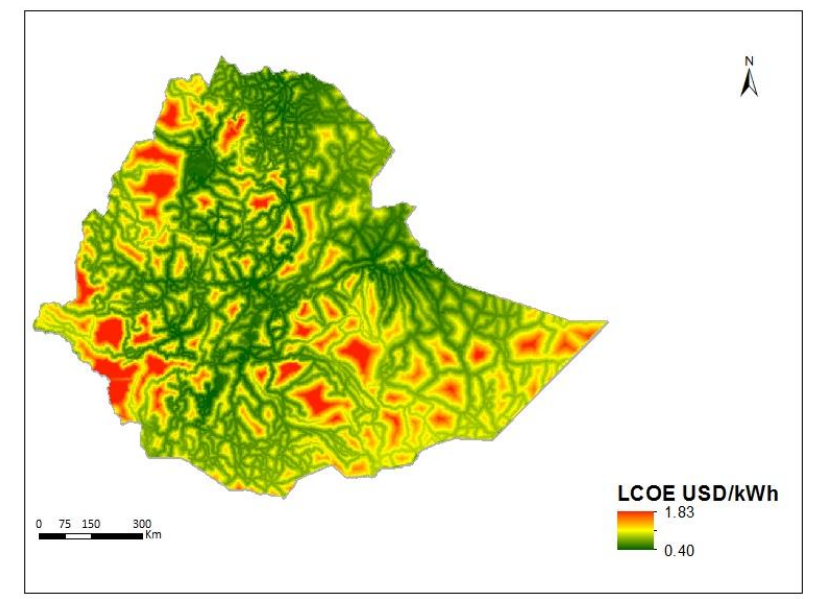

Figure 5: Levelized Cost of Electricity for diesel generation

Solar irradiation and wind power capacity factors displayed in Figure 6 are extracted from earlier work for the African continent (IRENA, 2014; Mentis et al., 2015). Further, the mini hydro (100 to $1000 \mathrm{~kW}$ ) power potential (IRENA, 2012) of Ethiopia is estimated by combining publicly available GIS datasets including Digital elevation map (CGIAR, 2008), Global river network (HydroSHEDS, 2013), Global Streamflow Characteristics Dataset (Beck et al., 2015; JRC, 2015), inland water bodies and restriction zones and shown in Figure 7. The technical potential (i.e. the potential that can be realized including general socio-economic and geographic exclusion criteria ${ }^{9}$ ); in each grid cell is translated into a cost and used as an input to the model for the mini grid and stand-alone options (see parametric analysis presented in Section 2.3).

${ }^{9}$ Explained in detail in (IRENA, 2014a; Mentis et al., 2015)) 

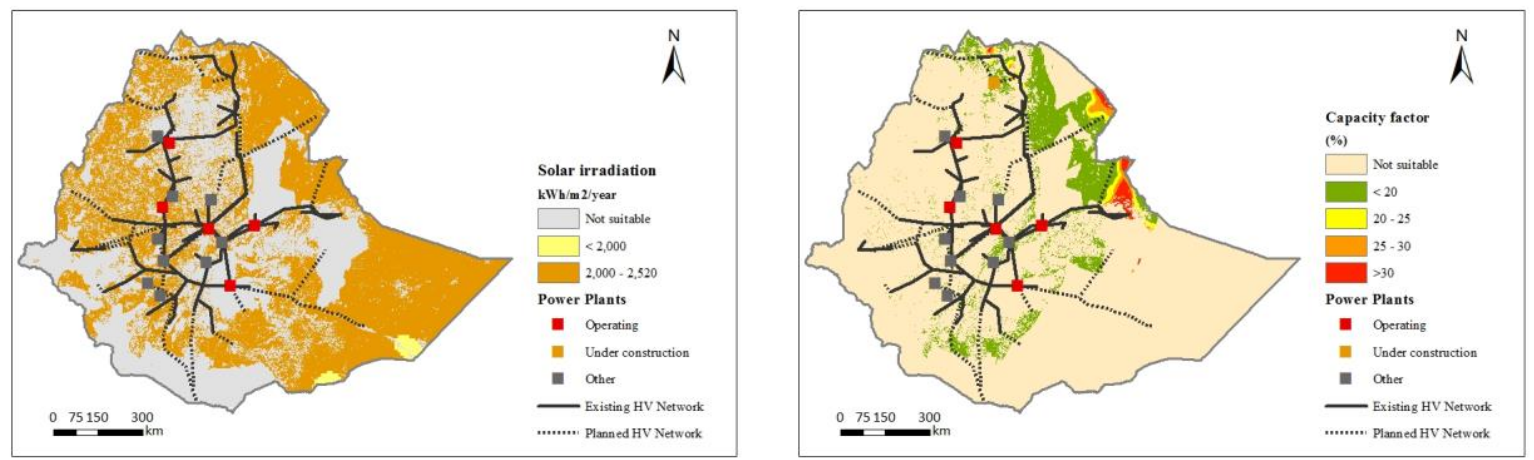

Figure 6: Solar irradiation (left) and wind power capacity factor (right)

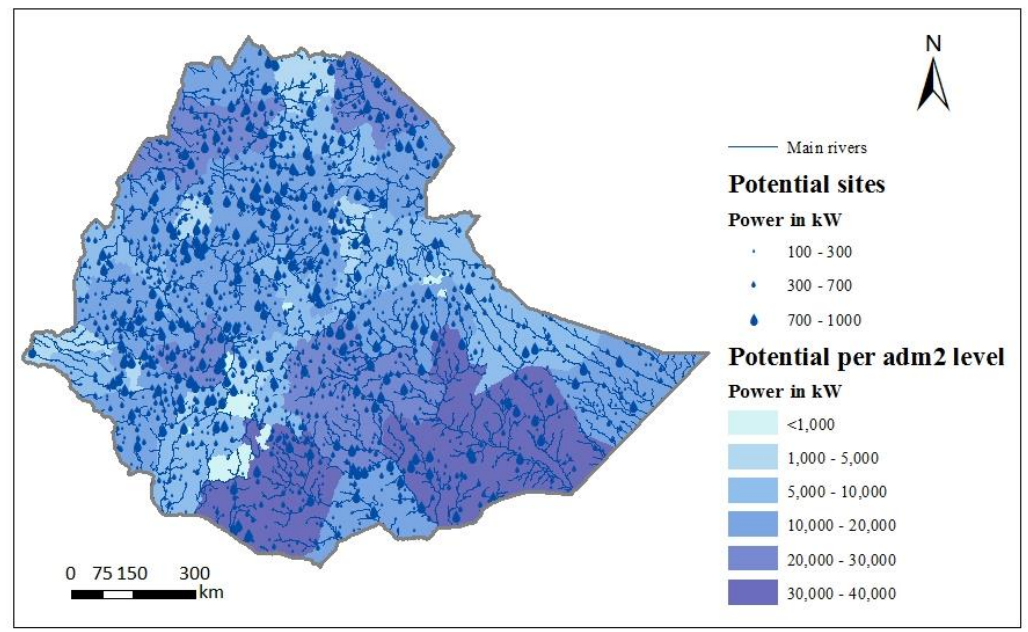

Figure 7: Mini hydro potential

The inclusion of detailed maps of renewable energy potential is a significant addition of this GIS based methodology. The higher the data resolution, the more accurate the corresponding cost estimations for site specific settlements.

\section{Results}

\subsection{Scenario results}

The following maps summarize the results of this techno-economic spatial analysis. The costoptimal split of on-grid, mini-grid and stand-alone solutions provide instructive insights abou the the future electrification in Ethiopia. The alternation of electricity access targets changes the optimal electrification mix and leads to different spatial infrastructure and technology configurations (see Figure 8).

The analysis shows that grid based connections are preferred for high consumption levels (blue in the following maps). For $93.4 \%$ of the newly electrified population, a connection to the grid constitutes the lowest cost option. Further, there is a high geo-spatial diversity in technology deployments and associated costs. This implies a mix of grid connected as well as local 
generation capacity to address electrification needs most efficiently. $5 \%$ of the population should be electrified by mini-grid solutions (green) and just about less than $1 \%$ by stand-alone systems (purple). It should be stated that electrification efforts differ depending on the extent of future HV and MV grid expansions.

Figure 8 illustrates the optimal electrification mix for two different rural per capita access targets: $50 \mathrm{kWh} /$ year and $150 \mathrm{kWh} /$ year. The urban access target was kept constant in order to capture the more challenging electrification access dynamics in rural settings. An analysis is carried out in order to assess how various rural electricity access targets influence the optimal split by varying the initial value of $150 \mathrm{kWh} /$ capita/year. The lower electricity access target 
results in higher penetration of stand-alone solutions, lesser population connected to the grid and lesser population electrified by mini grid systems.
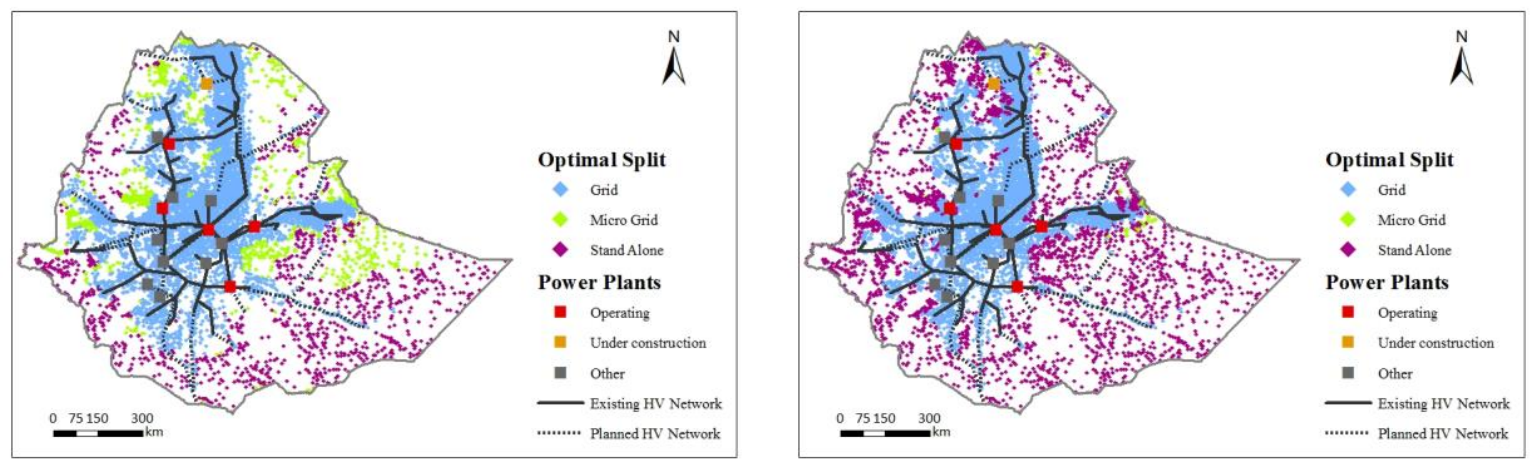

Figure 8: Optimal electrification mix in Ethiopia (electricity access targets: 150 and $300 \mathrm{kWh} / \mathrm{capita} / \mathrm{year}$ for the rural and urban areas respectively on the left graph; 50 and $300 \mathrm{kWh} / \mathrm{capita} / \mathrm{year}$ for the rural and urban areas respectively on the right graph)

Table 3 repeats the information shown in Figure 8 in tabular format. In the case of lower access targets for rural settlements, an additional $4.5 \%$ of the population is electrified with off-grid solutions.

Table 3: Population based optimal split for new connections for different rural electrification targets

\begin{tabular}{|l|l|l|l|}
\hline Split & $\begin{array}{l}\text { Population } \\
(150 / 300)\end{array}$ & $\begin{array}{l}\text { Population } \\
(50 / 300)\end{array}$ & Change \\
\hline Grid & 65431650 & 62270395 & $-4.8 \%$ \\
\hline Mini Grid & 3958695 & 245825 & $-93.8 \%$ \\
\hline Stand Alone & 656767 & 7530892 & $1046.7 \%$ \\
\hline
\end{tabular}
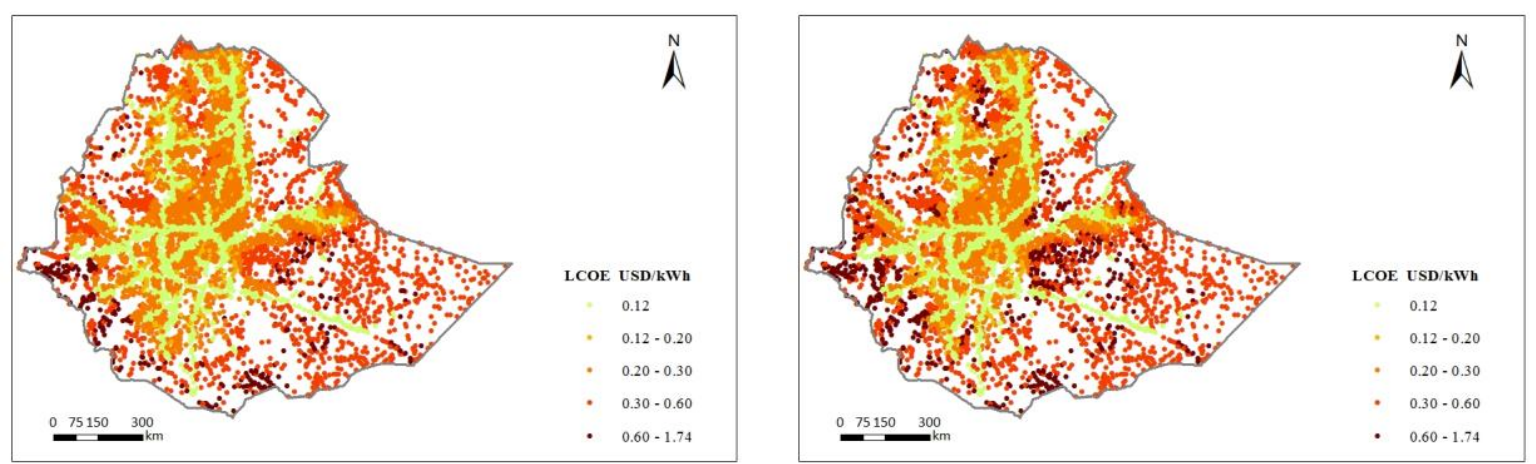

Figure 9: Spatial levelized cost of electricity for the two different rural electricity access targets; higher access on the left map (all technologies considered)

Error! Reference source not found.

Figure 9 shows the potential cost, in terms of LCOE, of providing electricity in different regions of Ethiopia. This includes considerations related to diesel costs based on distance from distribution stations, grid costs as a function of distance from grids, connection points and grid 
strengthening costs, geo-spatial solar irradiation, geo-spatial wind regimes and mini hydro potentials. LCOEs in areas supplied by grid electricity are lower than the LCOEs in areas with mini grid and stand-alone generation. The LCOEs are shown for identical rural electrification targets (150 and $50 \mathrm{kWh} /$ capita/person) - the higher the target, the lower the LCOE. LCOEs range from $0.12 \mathrm{US} \$ / \mathrm{kWh}$ in areas already connected to the national grid to $1.74 \mathrm{US} \$ / \mathrm{kWh}$ in remote areas with low population densities and electrified by stand-alone diesel generators.

The importance of geospatial electrification in context with local energy resource availability is demonstrated by two additional scenarios. One scenario (see Figure 10 left panel) considers only diesel stand-alone technologies to electrify cells without electricity access, while the other scenario considers the option to invest in stand-alone solar systems based on cost competitiveness. The deployment of PV stand-alone solutions decreases the levelized cost of electricity in some settlements as compared to diesel stand-alone supply. Stand-alone PV technology would be more viable for roughly 23 million (or $32 \%$ of the population that needs to be electrified). In case grid extension and mini grid technologies were to contribute to the electrification mix of the country, only a little more than 0.6 million people would be electrified by stand-alone systems (Diesel, PV) (Figure 8, Figure 9Error! Reference source not found.).
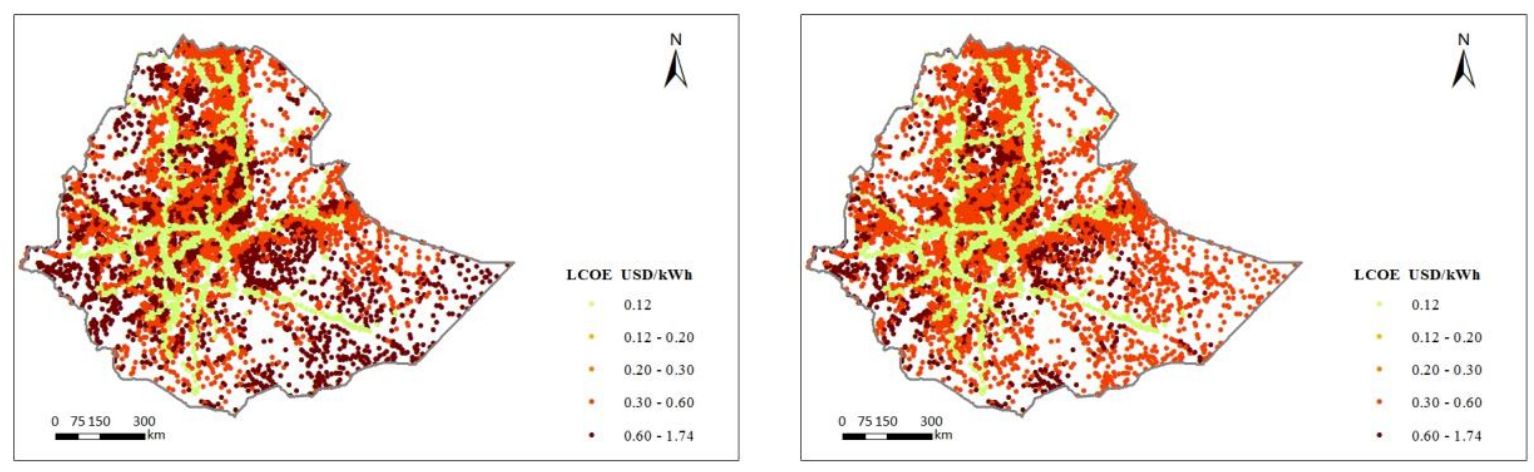

Figure 10: Spatial LCOE for the electricity access targets 150 (rural)-300 (urban) kWh/capita/year [on the left: Population already electrified is grid connected and the rest are electrified by Stand Alone Diesel, on the right: Population already electrified is grid connected and the rest are electrified by Stand Alone Diesel and PV]

With higher energy access targets least cost solutions shift from stand-alone to mini-grid and grid based options. Also, the deployment of renewable technologies rather than stand-alone diesel generators may provide electricity in a more economic and sustainable way. A sensitivity analysis, therefore, assessed how different rural electricity access targets would influence the optimal split by lowering the initial value of $150 \mathrm{kWh} /$ capita/year to $50 \mathrm{kWh} /$ capita/year. The urban access target was kept constant in order to capture the rural electricity access dynamics. Lowering rural electricity demand from $150 \mathrm{kWh}$ to $50 \mathrm{kWh}$ results in a shift from grid and mini grid supplies to stand alone generation.

\subsection{Spatial techno-economic results}


Table 4 summarizes the graphically presented findings numerically for the access targets of $150 / 300 \mathrm{kWh} /$ capita/year for rural and urban settlements respectively. Results regarding the grid expansion and the optimal electrification mix are directly derived from the geospatial analysis ${ }^{10}$.

The total length of the planned HV lines reaches $5,431 \mathrm{~km}$ in accordance to national plans and to cover mining activities, while based on this analysis $36,343 \mathrm{~km}$ of MV transmission and $513,407 \mathrm{~km}$ of distribution lines are required to provide universal electricity access.

Table 4: Optimal electrification mix for rural and urban access targets of 150 and $300 \mathrm{kWh} / \mathrm{capita} / \mathrm{year}$ respectively

\begin{tabular}{|l|l|l|}
\hline Item & Quantity & Unit \\
\hline Grid distribution & 7,844 & Settlements \\
\hline Grid distribution & $25,424,842$ & Households \\
\hline Grid distribution & $127,124,209$ & People \\
\hline $\begin{array}{l}\text { Planned grid expansion (Transmission } \\
\text { with HV lines) }\end{array}$ & 5,431 & $k m$ \\
\hline $\begin{array}{l}\text { Grid extensions for those gaining } \\
\text { access (Transmission with MV lines) }\end{array}$ & 36,343 & $k m$ \\
\hline $\begin{array}{l}\text { Grid extensions for those gaining } \\
\text { access (Distribution with MV \& LV } \\
\text { lines) }\end{array}$ & 513,407 & km \\
\hline Mini grids distribution & 915 & Settlements \\
\hline Mini grids distribution & 791,739 & Households \\
\hline Mini grids distribution & $3,958,695$ & People \\
\hline Mini grids power generation capacity & 0.34 & GW \\
\hline Mini grids power generation & 0.84 & TWh \\
\hline Stand-alone systems & 1060 & Settlements \\
\hline Stand-alone systems & 131,353 & Households \\
\hline Stand-alone systems & 0.032 & People \\
\hline Stand-alone systems power generation & 0.086 & \\
\hline Stand-alone systems power generation & 057 & \\
\hline
\end{tabular}

The investment and finance requirements for the grid expansion and the electricity generation are presented in Table 5. The total cost of household electrification (100\% electrification rate)

\footnotetext{
${ }^{10}$ The precision of the results is sensitive to the assumptions made in the model and the accuracy of the used data.
} 
and HV expansion to minerals totals US\$ 9.40 billion: US\$ 7.83 billion are required for grid electrification, US\$ 1.43 billion for mini grid electrification and US\$ 0.15 billion for standalone solutions.

Table 5: Investment needs for access to electricity

\begin{tabular}{|l|l|}
\hline Item & $\begin{array}{l}\text { Costs (billion US } \\
\text { dollar 2013) }\end{array}$ \\
\hline $\begin{array}{l}\text { Planned grid expansion } \\
\text { (Transmission with HV lines) }\end{array}$ & 0.721 \\
\hline $\begin{array}{l}\text { Grid extensions for those gaining } \\
\text { access (Transmission with MV } \\
\text { lines) }\end{array}$ & 0.327 \\
\hline $\begin{array}{l}\text { Grid extensions for those gaining } \\
\text { access (Distribution with MV \& } \\
\text { LV lines) }\end{array}$ & 6.781 \\
\hline $\begin{array}{l}\text { Mini grids power generation } \\
\text { capacity }\end{array}$ & 1.425 \\
\hline $\begin{array}{l}\text { Stand-alone systems power } \\
\text { generation capacity }\end{array}$ & 0.147 \\
\hline $\begin{array}{l}\text { Total household } \\
\text { electrification cost }\end{array}$ & $\mathbf{9 . 4 0 2}$ \\
\hline
\end{tabular}

The mini grid and stand-alone technologies split is depicted in Table 6. Diesel generators and solar photovoltaics provide the largest shares of electricity for off grid solutions. Solar technologies are key to setting up a large number of off-grid systems at small amounts of electricity consumption. At higher levels of electricity demand, there is a tendency to rely more on mini-grids powered by diesel generators and, where available, small hydropower.

Table 6: Population Split - off grid solutions

\begin{tabular}{|l|l|l|l|l|}
\hline Off grid options & Diesel & PV & Wind & Small hydro \\
\hline Mini grid & $45.6 \%$ & $31.6 \%$ & $0.9 \%$ & $21.9 \%$ \\
\hline Stand-alone & $46.4 \%$ & $53.6 \%$ & - & - \\
\hline
\end{tabular}




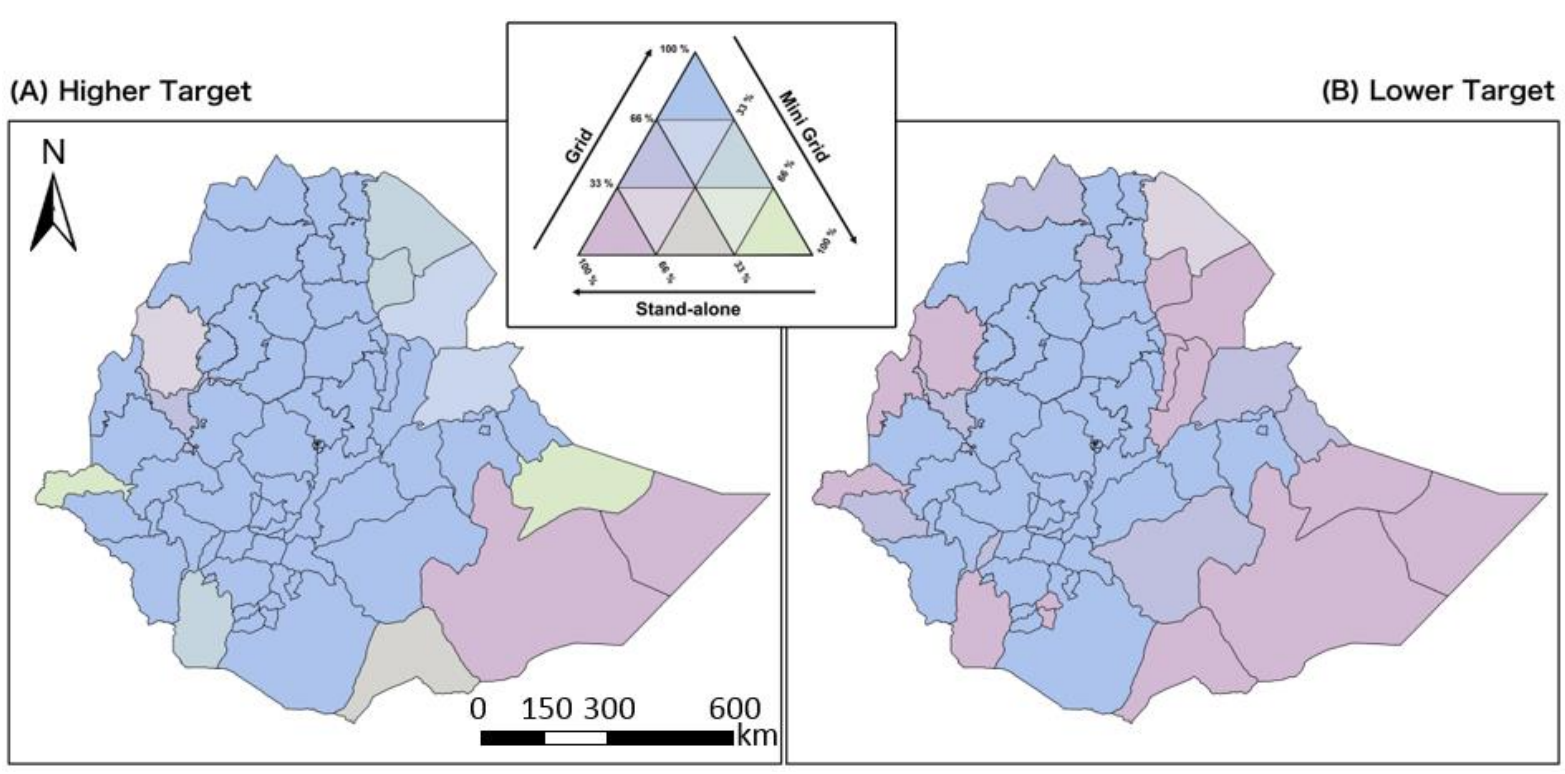

Figure 11: Spatial distribution of modal split: High target (left panel A) and Low target (right panel B)

Figure 11 maps the spatial distribution of the modal split between Grid, Mini Grid and Standalone solutions of the High target (Panel A) and Low target (Panel B) to "zone" levels. The figure distinguishes three categories of technology penetration: $1-33 \%, 34-66 \%$ and $67-100 \%$ of electrification by either grid, mini grid or stand-alone systems.

In case of the High target grids are the dominant solution to electrification (67-100/\%) in jurisdictions located in the central part of the country supplemented by mini grids (1-33\%). The jurisdictions in the southeastern part of the country are distinctly different: Stand-alone systems account for $67-100 \%$ of electrification and only 1-33\% are supplied by grids. Two provinces marked green in Panel A stand out, i.e., they remain off-grid. Here mini grids dominate electricity supplies (67-100\%) while stand-alone systems make up the remainder.

The second map (B) shows the spatial distribution associated with the Low target. The main change occurs in jurisdictions bordering neighboring countries. Stand-alone systems account for $66-100 \%$ of the electrification and grids for less than $33 \%$. The central parts of the country are not markedly affected by the two different access targets. The two jurisdictions standing out in Panel A, i.e., with mini-grid as the main solution, adjusted their modal split. Now standalone systems (67-100\%) replace mini-grids which are essentially eliminated from the electrification mix as the as grid based electricity makes up the slack.

\section{Discussion}

The application of the GIS methodology has led to a number of important insights. Stand-alone solar can play a key role in providing basic energy access to a fair amount of the population cost-effectively (ca. 650 thousand people). However, with increasing demand, stand-alone solar loose attractiveness and mini- and grid solutions become more competitive. When demand in rural areas increases from 50 to $150 \mathrm{kWh} /$ capita, PV stand-alone systems drop from supplying electricity to $11 \%$ of the population to a mere $1 \%$. 
Diesel prices play a key role in determining their deployment. Their variation in time and space as well as their environmental cost should be further studied to conclude to the viability of this option. For high population density settlements and high demand, grid connections remain the preferred option.

However, there are several limitations of this analysis which are noteworthy. The analysis cannot replace engineering load-flow analysis which is necessary to implement grid expansions (Powell, 2004). Investments are made over night which not only assumes finance, manufacturing capacity and human resources are freely available but also instant decision making. For example, grid expansions are usually public sector affairs and known to involve time consuming procedures. A lengthy decision making process would leave many people without electricity for extended periods of time. Therefore, the important role of off-grid solutions to speed up electrification of remote areas (with an option of a connection to the main grid at a later point) (Welsch et al., 2013) is not assessed in this paper, which relies purely on cost comparisons of the three principal electrification options. Moreover, the current spatial electrification status of the country is based on assumptions related to the geo-referenced population density and the transmission network. As a next step, the latter and the estimation of electricity consumption levels could be enhanced with the addition of information obtained by night-time light maps and other remote sensing datasets (Min et al., 2013), (Azevedo et al., 2016).

Furthermore, the provision of electricity is essential to the achievement of SDGs. Studies indicate that the very first kilowatt-hours provided, already bring great benefits to human development. The level and the quality of education, the quality of health services, gender equality, indoor environment can all be improved with access to modern energy services (Javadi et al., 2013),(Kanagawa and Nakata, 2008), (Mondal and Klein, 2011). Although the impacts of access to electricity on the attainment of other SDGs were out of scope of this study, early electrification remains a key enabler for socio-economic development.

The maps presenting the electrification split use zones as spatial unit. The relatively large sizes of these spatial units are a major constraint when one attempts to relate the spatial electrification patterns to local neighbourhood effects. Therefore, the study suggests an in-depth analysis using a higher resolution (most preferable on district levels) to evaluate clustering and neighbourhood effects in the analyses.

Nonetheless, this approach provides informative insights on which areas should in any case be connected by off-grid solutions. In settlements where this analysis suggests should be connected to the main grid, detailed power planning is required to understand whether or not and, if, when such a connection should be implemented, or if mini- and off-grid solutions may be preferable to ramp up electrification efforts.

\section{Conclusions}

To optimize national electrification strategies and their subsequent policies, developing governments need to identify technology solutions that are best suited for a given geographical area. With energy services being increasingly delivered in a decentralized manner often by nongovernmental actors, the 'to grid or not to grid' question becomes increasingly imminent. GIS based analysis assists governments in evaluating on-grid and off-grid options, in developing national electrification strategies and formulating coherent and effective electrification policies. 
Cost effective electricity supply systems serving rural households and businesses are diverse and site specific. In short, location matters. The cost-optimal technology choice thus depends on several geographically determined parameters - population density, distance to the grid, fuel costs, and electricity demand as well as wind regimes, mini-hydro sites, settlement locations and grid infrastructures. Developing a clear transparent approach to capturing these parameters, translating them into sets of technology options to meet energy access goals is crucial to informing effective policy.

GIS based modelling responds to this need by enabling the analyst to assess the cost of electricity supply at any location in a given area. By combining detailed geo referenced layers of data for each relevant parameter, site specific investment needs and energy cost implications of competing technological systems can be compared.

The presented approach complements the existing energy planning models, which do not consider the geospatial characteristics of electricity demand and supply, but may, for example, help determine the least-cost structure of the electricity generating mix supplying current and future national and regional grids. Combined GIS and traditional energy planning ease the communication of the assumptions and findings of rather complex assessments, thus help narrow the current science-policy gap.

Reaching universal access to electricity in Ethiopia is necessary to ensure economic and social development in the country. Past electrification policies have promoted off-grid solutions to advance rural electrification. This study indicates the significance of integrated planning using a wide range of technology options to provide access to electricity to non-electrified populations. The implementation of GIS in energy planning can help policy makers and planners to independently identify areas with the lowest rate of electricity access and rationalize decision-making as well as providing an efficient monitoring tool.

\section{Acknowledgments}

Nora Selmet (IEA), Fatih Birol (IEA), Brent Wanner (IEA), Laura Cozzi (IEA), Timur Guel (IEA) and Jane Hammarstrom (USGS), for the contribution in data collection, Eigo Tateishi (MAH) for cartographic assistance, and the Swedish International Development Cooperation Agency (SIDA) for financing the project contribution to IEA World Energy Outlook 2014. We also acknowledge funding from the Swedish Science Council, Vetenskapsrådet, Sweco-J. Gust. Richert foundation and ABB. 


\section{References}

1. AfDB, 2011. Maps | Africa Infrastructure Knowledge Program [WWW Document]. URL http://www.infrastructureafrica.org/tools/maps (accessed 1.19.15).

2. Archer, C.L., Jacobson, M.Z., 2013. Geographical and seasonal variability of the global "practical" wind resources. Appl. Geogr. 45, 119-130. doi:10.1016/j.apgeog.2013.07.006

3. Archila Bustos, M., Hall, O., Andersson, M., 2015. Nighttime lights and population changes in Europe 1992-2012. Ambio 44, 653-665. doi:10.1007/s13280-015-0646-8

4. Aydin, N.Y., Kentel, E., Sebnem Duzgun, E., 2013. GIS-based site selection methodology for hybrid renewable energy systems: A case study from western Turkey. Energy Convers. Manag. 70, 90-106. doi:10.1016/j.enconman.2013.02.004

5. Azevedo, J.A., Chapman, L., Muller, C.L., 2016. Urban heat and residential electricity consumption: A preliminary study. Appl. Geogr. 70, 59-67. doi:10.1016/j.apgeog.2016.03.002

6. Balta-Ozkan, N., Watson, T., Mocca, E., 2015. Spatially uneven development and low carbon transitions: Insights from urban and regional planning. Energy Policy 85, 500-510. doi:10.1016/j.enpol.2015.05.013

7. Beck, H.E., de Roo, A., van Dijk, A.I.J.M., 2015. Global Maps of Streamflow Characteristics Based on Observations from Several Thousand Catchments. J. Hydrometeorol. 16, 1478-1501. doi:10.1175/JHM-D-14-0155.1

8. Bekele, G., Tadesse, G., 2012. Feasibility study of small Hydro/PV/Wind hybrid system for off-grid rural electrification in Ethiopia. Appl. Energy, Energy Solutions for a Sustainable World - Proceedings of the Third International Conference on Applied Energy, May 16-18, 2011 - Perugia, Italy 97, 5-15. doi:10.1016/j.apenergy.2011.11.059

9. Blöschl, G., Sivapalan, M., 1995. Scale issues in hydrological modelling: A review. Hydrol. Process. 9, 251-290. doi:10.1002/hyp.3360090305

10. Calvert, K., Mabee, W., 2015. More solar farms or more bioenergy crops? Mapping and assessing potential land-use conflicts among renewable energy technologies in eastern Ontario, Canada. Appl. Geogr. 56, 209-221. doi:10.1016/j.apgeog.2014.11.028

11. CGIAR, 2008. SRTM 90m Digital Elevation Database v4.1 | CGIAR-CSI.

12. ESMAP, 2015. URL http://www.esmap.org/RE_Mapping

13. Fuso Nerini, F., Broad, O., Mentis, D., Welsch, M., Bazilian, M., Howells, M., 2015. A cost comparison of technology approaches for improving access to electricity services. Energy.

14. GADM, 2012. Global Administrative Areas | Boundaries without limits [WWW Document]. URL http://www.gadm.org/ (accessed 1.19.15).

15. Gormally, A.M., Whyatt, J.D., Timmis, R.J., Pooley, C.G., 2012. A regional-scale assessment of local renewable energy resources in Cumbria, UK. Energy Policy, Special Section: Past and Prospective Energy Transitions - Insights from History 50, 283-293. doi:10.1016/j.enpol.2012.07.015

16. Howells, M., Rogner, H., Strachan, N., Heaps, C., Huntington, H., Kypreos, S., Hughes, A., Silveira, S., DeCarolis, J., Bazillian, M., Roehrl, A., 2011. OSeMOSYS: The Open Source Energy Modeling System. Energy Policy 39, 5850-5870. doi:10.1016/j.enpol.2011.06.033

17. HydroSHEDS, 2013. Global River Network [WWW Document]. URL http://hydrosheds.cr.usgs.gov/dataavail.php

18. IEA, 2015. World Energy Outlook. Organisation for Economic Co-operation and Development, Paris.

19. IEA, 2014a. IEA - Energy poverty [WWW Document]. URL http://www.iea.org/topics/energypoverty/ (accessed 1.13.15).

20. IEA, 2014b. IEA - Energy access database [WWW Document]. URL http://www.worldenergyoutlook.org/resources/energydevelopment/energyaccessdatabase/ (accessed 1.15.15). 
21. IEA, 2014c. World Energy Outlook (No. 1026-1141). Organisation for Economic Cooperation and Development, Paris.

22. IEA, 2011. IEA - Access to Electricity [WWW Document]. URL http://www.iea.org/publications/worldenergyoutlook/resources/energydevelopment/access toelectricity/ (accessed 1.13.15).

23. IFPRI, 2009. ETHIOPIA STRATEGY SUPPORT PROGRAM II (ESSP - II) Urbanization and Spatial Connectivity in Ethiopia.

24. IIASA, 1981. The Energy Supply Model MESSAGE.

25. IRENA, 2014. Estimating the Renewable Energy Potential in Africa A GIS-based approach.

26. IRENA, 2012. Renewable energy technologies: Cost analysis series; Hydropower.

27. Javadi, F.S., Rismanchi, B., Sarraf, M., Afshar, O., Saidur, R., Ping, H.W., Rahim, N.A., 2013. Global policy of rural electrification. Renew. Sustain. Energy Rev. 19, 402-416. doi:10.1016/j.rser.2012.11.053

28. JRC, 2015. European Commission Joint Research Centre: Global Streamflow Characteristics Dataset [WWW Document]. URL http://water.jrc.ec.europa.eu/GSCD/

29. JRC, 2008. Land Resource Management [WWW Document]. URL http://bioval.jrc.ec.europa.eu/products/gam/download.htm (accessed 1.19.15).

30. Kanagawa, M., Nakata, T., 2008. Assessment of access to electricity and the socioeconomic impacts in rural areas of developing countries. Energy Policy 36, 2016-2029. doi:10.1016/j.enpol.2008.01.041

31. Künneke, R.W., 2008. Institutional reform and technological practice: the case of electricity. Ind. Corp. Change 17, 233-265. doi:10.1093/icc/dtn002

32. Linard, C., Gilbert, M., Snow, R.W., Noor, A.M., Tatem, A.J., 2012. Population Distribution, Settlement Patterns and Accessibility across Africa in 2010. PLoS ONE 7, e31743. doi:10.1371/journal.pone.0031743

33. Loulou, R., Remme, U., Kanudia, A., Lehtila, A., Goldstein, G., 2005. Documentation for the TIMES Model Part I.

34. Mentis, D., Hermann, S., Howells, M., Welsch, M., Siyal, S.H., 2015b. Assessing the technical wind energy potential in Africa a GIS-based approach. Renew. Energy 83, 110125. doi:10.1016/j.renene.2015.03.072

35. Mentis, D., Hermann, S., Howells, M., Welsch, M., Siyal, S.H., 2015a. Assessing the technical wind energy potential in Africa A GIS-based approach. Renew. Energy.

36. Miller, A., Li, R., 2014. A Geospatial Approach for Prioritizing Wind Farm Development in Northeast Nebraska, USA. ISPRS Int. J. Geo-Inf. 3, 968-979. doi:10.3390/ijgi3030968

37. Min, B., Gaba, K.M., Sarr, O.F., Agalassou, A., 2013. Detection of rural electrification in Africa using DMSP-OLS night lights imagery. Int. J. Remote Sens. 34, 8118-8141. doi:10.1080/01431161.2013.833358

38. Mondal, A.H., Klein, D., 2011. Impacts of solar home systems on social development in rural Bangladesh. Energy Sustain. Dev. 15, 17-20. doi:10.1016/j.esd.2010.11.004

39. Nijkamp, P., 1980. Energy problems and regional development: Editorial note. Reg. Sci. Urban Econ. 10, 299-301.

40. Palaiologou, P., Kalabokidis, K., Haralambopoulos, D., Feidas, H., Polatidis, H., 2011. Wind characteristics and mapping for power production in the Island of Lesvos, Greece. Comput. Geosci. 37, 962-972. doi:10.1016/j.cageo.2010.05.025

41. Phillips, J.D., 1988. The Role of Spatial Scale in Geomorphic Systems. Geogr. Anal. 20, 308-317. doi:10.1111/j.1538-4632.1988.tb00185.x

42. Pollet, B.G., Staffell, I., Adamson, K.-A., 2016. Energy and Africa, in: The Energy Landscape in the Republic of South Africa, SpringerBriefs in Energy. Springer International Publishing, pp. 3-12. 
43. Pollitt, M., 2008. The arguments for and against ownership unbundling of energy transmission networks. Energy Policy 36, 704-713. doi:10.1016/j.enpol.2007.10.011

44. Powell, L., 2004. Power System Load Flow Analysis, 1 edition. ed. McGraw-Hill Education, New York.

45. Quattrochi, D.A., Goodchild, M.F., 1997. Scale in remote sensing and GIS. Lewis Publishers, Boca Raton, Fla.

46. Quinonez-Varela, G., Cruden, A., Graham, C., Punton, B., Blair, L., Thomson, J., 2007. A GIS/PSS planning tool for the initial grid connection assessment of renewable generation. Renew. Energy 32, 727-737. doi:10.1016/j.renene.2006.03.011

47. Resch, B., Sagl, G., Törnros, T., Bachmaier, A., Eggers, J.-B., Herkel, S., Narmsara, S., Gündra, H., 2014. GIS-Based Planning and Modeling for Renewable Energy: Challenges and Future Research Avenues. ISPRS Int. J. Geo-Inf. 3, 662-692. doi:10.3390/ijgi3020662

48. Sahai, D., 2013. Toward universal electricity access : renewable energy-based geospatial least-cost electrification planning (No. 84314). The World Bank.

49. SE4ALL, 2015. GLobal Tracking Framework Report. Progress toward sustainable energy.

50. Siyal, S.H., Mörtberg, U., Mentis, D., Welsch, M., Babelon, I., Howells, M., 2015. Wind energy assessment considering geographic and environmental restrictions in Sweden: A GIS-based approach. Energy 83, 447-461. doi:10.1016/j.energy.2015.02.044

51. Sørensen, B., Meibom, P., 1999. GIS tools for renewable energy modelling. Renew. Energy, Renewable Energy Energy Efficiency, Policy and the Environment 16, 1262-1267. doi:10.1016/S0960-1481(98)00514-X

52. Turner, R.K., 1989. Economics and environmentally sensitive aid. Int. J. Environ. Stud. 35, 39-50. doi:10.1080/00207238908710548

53. UNDESA, 2015a. Proposal for Sustainable Development Goals .. Sustainable Development Knowledge Platform [WWW Document]. URL https://sustainabledevelopment.un.org/sdgsproposal (accessed 6.4.15).

54. UNDESA, 2015b. United Nations Department of Economic and Social Affairs, Population Division [WWW Document]. URL http://esa.un.org/unpd/wpp/

55. UNDESA, 2013. United Nations Statistics Division - Demographic and Social Statistics [WWW Document]. URL http://unstats.un.org/unsd/demographic/sconcerns/densurb/densurbmethods.htm (accessed 1.19.15).

56. USGS, 2014. USGS Mineral Resources On-Line Spatial Data [WWW Document]. URL http://mrdata.usgs.gov/ (accessed 1.19.15).

57. Wei, Y.D., 2015. Spatiality of regional inequality. Appl. Geogr. 61, 1.

58. Welsch, M., Bazilian, M., Howells, M., Divan, D., Elzinga, D., Strbac, G., Jones, L., Keane, A., Gielen, D., Balijepalli, V.S.K.M., Brew-Hammond, A., Yumkella, K., 2013. Smart and Just Grids for sub-Saharan Africa: Exploring options. Renew. Sustain. Energy Rev. 20, 336-352. doi:10.1016/j.rser.2012.11.004

59. WHO, 2009. WHO | The Energy Access Situation in Developing Countries [WWW Document]. URL http://www.who.int/indoorair/publications/energyaccesssituation/en/ (accessed 1.13.15).

60. Ye, X., Wei, Y.D., 2005. Geospatial Analysis of Regional Development in China: The Case of Zhejiang Province and the Wenzhou Model. Eurasian Geogr. Econ. 46, 445-464. doi:10.2747/1538-7216.46.6.445 